\title{
FIRM SIZE AS DETERMINANTS OF INTELLECTUAL CAPITAL DISCLOSURE
}

\author{
Fitri Ella Fauziah \\ Universitas Islam Nahdlatul Ulama, Jepara \\ Email : fitriella@unisnu.ac.id (corresponding author) \\ Murharsito \\ Universitas Islam Nahdlatul Ulama, Jepara \\ Email : murharsito@unisnu.ac.id
}

Received: November 2020; Accepted: February 2021; Available online: July 2021

\begin{abstract}
The objective of this research was to investigate the effect of size of firm, leverage, audit committee and business complexity on the disclosure of intellectual capital. The sample of this study was manufacturing firms in the basic industrial and chemical sub sectors that registered on the Indonesia Stock Exchange in the period of 2019. The sample was determined by using a method of purposive sampling, there were 104 samples. This research used multiple linear regression methods. Partly, the results of this analysis show that only firm size has an influence on intellectual capital disclosure. Meanwhile, the audit committee, business complexity and leverage have no significance on the disclosure of intellectual capital.
\end{abstract}

Keywords: firm size; leverage; audit committee; business complexity; intellectual capital disclosure.

\begin{abstract}
Abstrak
Tujuan dari penelitian ini yaitu untuk menginvestigasi pengaruh ukuran perusahaan, leverage, komite audit dan kompleksitas bisnis terhadap pengungkapan modal intelektual. Sampel yang dipakai dalam penelitian ini adalah perusahaan manufaktur dari sub sektor industri dasar dan kimia yang tercatat di Bursa Efek Indonesia pada periode 2019. Penentuan sampel dilakukan dengan menggunakan metode purposive sampling yang diperoleh sejumlah 104 sampel. Metode analisis yang dipakai dalam penelitian ini adalah analisis regresi berganda. Secara parsial, hasil dari analisis menunjukkan bahwa hanya ukuran perusahaan yang memiliki pengaruh terhadap pengungkapan intellectual capital. Sedangkan komite audit, kompleksitas bisnis dan leverage tidak memiliki pengaruh terhadap pengungkapan modal intelektual.
\end{abstract}

Kata kunci: ukuran perusahaan; leverage; komite audit; kompleksitas bisnis; pengungkapan modal intelektual.

How to Cite: Fauziah, F. E., \& Murharsito (2021). Firm Size as Determinants of Intellectual Capital Disclosure. Media Ekonomi dan Manajemen, 36(2), 136-155. doi: http://dx.doi.org/ 10.24856/mem.v36i2.1820.

\section{INTRODUCTION}

Companies can get good performance with the support of stakeholders including creditors and investors. These stakeholders need some company information for making investment decisions and providing loans to companies. In addition, stakeholders also need infor- mation related to the company's intellecttual capital, so disclosure of intellectual capital of the company is very important.

The disclosure of the firm's intellectual capital can be a good signal for the company and help stakeholders in making these decisions. This is also stated by Bukh (2003) which states that the disclosure of intellectual capital is very 
vital for investors because it can help investors to identify and lessen uncertainty in evaluating company performance.

A company's intellectual capital includes structures, human resources, intellectual property, organizational routines, and relationships between the firm and its consumers, providers, wholesalers and business partners (Subaida, Nurholis \& Mardiati, 2018). Thus the company needs to disclose these intellectual capital items to meet the needs of interested party.

Some of the factors that influence companies to disclose intellectual capital include corporate governance, profitability, company extent, leverage, and the type of industry. There are a lot of research on the disclosure of intellectual capital, but it still produces mixed research results and this research seeks to re-test the issue of intellectual capital revelation according to the differences in the outcomes of these studies. This article used the variables of company size, leverage, audit committee and business complexity.

The firm size variable can show how many assets the company owns. Companies with a large size can disclose a lot of company intellectual capital information, such as research conducted by Faradina (2016), Leonard (2015), Setiono and Rudiawarni, (2017), and Isnalita (2018) which concluded that company size has a significant effect on intellectual capital revelation with positive direction . But the results of this research contradict the findings of research done by Nugroho, (2012), and Ashari and Putra (2016) which state that company size has no effect on intellectual capital disclosure.

Leverage is the level of debt a company has, a corporation with a great level of liability can influence the company to disclose its intellectual capital. Research that examines the relationship between leverage and revelation of intellectual capital was done by Bruggen, Vergauwen and Dao (2009), Rashid, Ibrahim, Othman, and See (2012), and Damayanti and Budiyanawati (2014) stated that leverage has a positive and significant influence on revelation of intellectual capital, but the research conducted by Nugroho, (2012), Faradina, (2016), and Ashari and Putra, (2016) stated that leverage has insignificant effect.

The audit committee is one elements in corporate governance which is responsible to produce the company's financial performance. According to Ho and Shun Wong (2001) the existence of an audit committee in a company creates the reliability of financial reporting, increases quality and disclosure. There are dissimilarities in the results of an investigation that examines the audit committee on intellectual capital disclosures produced by $\mathrm{Li}$, Mangena and Pike (2012), Haji, A.A. (2015), Hatane, Kuanda, Cornelius ,and Tarigan (2020), Taliyang and Jusop (2011), and Isnalita (2018). Li et al. (2012), and Balasundaram, (2018) which revealed that the audit committee has a positive impact on the disclosure intellectual capital. However, $\mathrm{Li}$ et. al. (2012), and Zulkarnaen (2013) provided the result that this committee has no influence on the disclosure of intellectual capital.

Business complexity is the number of operational activities the firm carries out, which is reflected in the number of subsidiaries. The large number of subsidiaries requires solid coordination so that between subsidiaries can assist the monitoring carried out by company management, so that company management needs to provide intellectual capital disclosure to overcome these obstacles. Banjarnahor (2019), Hossain and Hammami (2009), and Haniffa and Cooke (2002) provides research results that show that business complexity affects intellecttual capital disclosure. However, according to research results Jindal and Kumar (2012), Setiono and Rudiawarni, (2017), Afrizal, Hakiem, and Sensuse (2015), and Jindal and Kumar, (2012) business complexity has no influence on this disclosure. 
This research was done on basic and chemical industry sub-sector firms registered on the IDX for the 2017-2018 period. Basic and chemical industrial companies are one of the sectors that have a fairly high growth in 2018, approximately around $21.17 \%$. Besides that, there are many studies conducted research on manufacturing companies. Thus, the outcomes of this research can provide different results from previous studies.

With regards on the background and formulated problem, the research questions posed in this study was does audit committee, business complexity, company size and leverage affect intellectual capital partially and simultaneously?

\section{LITERATURE REVIEW}

\section{Agency Theory}

Agency theory is a condition in which management acts as an agent to carry out the firm's operational actions in order to generate profits for the owner (principal). Scott, Carcello, and Hollingsworth (2015) states agency theory as a contractual affiliation among the principal and the agents, the principal as the party who employs the agent to perform tasks for the interests of the principal and the agent as the party carrying out the interests of the principal.

Thus, the agent runs the company using funds owned by the principal. This relationship gives rise to the principalagent asymmetry of information where the agent has more information than the principal and not all information is presented to the principal. The principal wants the profit to be obtained through a share of the profit, while the agent seeks to obtain prosperity for himself.

\section{Stakeholders Theory}

Companies cannot carry out their activities without the help of other parties, in this case the stakeholders. Stakeholders include investors, creditors, customers, suppliers, government and society. The company's success is influenced by the company's relationship with stakeholders.

According to Ghazali and Chariri (2007), stakeholder theory provides the view that a firm is not a unit operating for its own interests, but also a unit that can provide benefits to stakeholders. Thus, the company's survival depends on the support of stakeholders, the greater the support from stakeholders for the company, the greater the company's efforts to adapt.

Companies need to disclose information in financial reports that can assist stakeholders in making decisions, so as to minimize losses that can occur for stakeholders. In addition, it can also establish good relationships with stakeholders

\section{Intellectual Capital Disclosure}

Bukh et.al (2005) defined intellectual capital as knowledge related to resources such as: workers, consumers, processes and technology that companies can use in the value making process, while Nugroho (2012) described intellectual capital as knowledge, information and intellectual property can determine opportunities and threat management in the life of the company, so that it can affect the endurance and competitive advantage in various ways. Thus the existence of intellectual capital is very important for the company so it is also very important to be informed to stakeholders in the firm's annual financial report. Stakeholders can analyze the conditions of the firm in order to support decision making.

Several reasons underlie companies to provide disclosure of intellectual capital information into annual financial reports, including 1) to assist organizations in formulating strategies, 2) to assess strategic decision making, 3) to assist decision making related to diversification and expansion, 4) to be used as a foundation for providing compensation, 5) to communicate measurements to outside stakeholders (Marr, Mouritsen, and Bukh, 2003). According to Boedker et al., (2005) 
in Nafisah and Meiranto (2017), intellectual capital can be divided into three main pillars which include human capital (HC) and structural capital (SC) as well as relational capital (RC). Furthermore, Human capital is a collection of knowledge, leadership, abilities, cooperation and other capacities possessed by individual employees. Structural capital includes organizational structure, management processes, knowledge and research \& development. Relational capital relates to external stakeholders, including brand, image or commercial power.

\section{Firm Size}

Firm size is an identification of the largeness of the company based on certain measurements. Sujoko and Soebiantoro (2007) stated that size o firm is a reflection of the extent of the corporation as seen from the overall asset value of the firm on the annual balance sheet. Large companies have a tendency to have a variety of activities, this is because large companies have all the resources that can support these activities. This will have an impact on the development of a larger company and become a positive signal for stakeholders.

\section{Leverage}

Leverage can be determined by the calculation of total debt divided by total equity. The debt is funds obtained from creditors, while equity is the capital or funds owned by the company. Asfahani (2017) reveals leverage as the proportion of company debt to total assets at the year ending, is used to quantity how much the company is dependent in managing funds obtained from creditors.

Leverage provides an overview of the company's capital structure so that the leverage ratio can tell how much the company can fulfil its obligations. If the amount of company debt is higher than the amount of equity, this indicates that the company is dependent on financing its operational activities compared to its own capital. This indicates that the company's financial condition can experience financial distress.

\section{Audit Committee}

According to the 2011 OJK rule, the audit committee is made by and has a responsibility to the Board of Commissioners, fulfilling the duties and functions of the Board of Commissioners. The obligations of the audit committee are: (a) checking commercial information that will be supplied by the issuer to the community, containing financial reports, prognoses and other reports associated with the financial data of the issuer or public corporation; (b) conducting an assessment of compliance with regulations and laws connecting to the actions of the issuer or public corporation; (c) delivering independent view in the happening of dissimilarities between managing body and the auditor for the services rendered; (d) delivering recommendations to the Commissioners Board about the selection of an auditor based on independence, task scope, and service levies; (e) examining the operation of audits by internal auditors and controlling the application of followups by the Board of Directors on the results of the internal auditors; (f) assessing the risk management actions implemented by the Board of Directors, if a risk monitoring function under the board of commissioner is not possessed by the Issuer or Public Corporation; reviewing complaints connecting to the accounting and reporting of financial procedures of Issuers or Public Corporations; (g) reviewing and giving advice to the Board of Commissioners about possible conflicts of interest of the Issuer or Public Corporation; and (h) Keeping the confidentiality of data, documents, and information of the Issuer or Public Corporation.

\section{Business Complexity}

Banjarnahor (2019) defined business complexity as a company's business structure that is reflected in the total of 
subsidiaries possessed by a company. Companies that have experienced fairly high development in their operating activities are usually indicated by the number of business expansions through the establishment of subsidiaries. Subsidiaries carry out their operational activities under the control of the parent firm, because part or all of their capital is possessed by the parent firm. Regarding the location of operational activities, the parent company and the subsidiary may have separate operating locations.

Companies with various business lines and subsidiaries require companies to synergize one subsidiary company with another. This is because the company must provide information related to its subsidiaries in one financial report, namely the annual financial report. This report is used to meet stakeholder needs in decision making.

\section{Hypothesis}

\section{The Influence of Firm Size on Intellec- tual Capital Disclosure}

Firm size shows the largeness of a firm which can be measured by various proxies, including by looking at the amount of assets. If the amount of assets is large, it can be categorized as a large company and vice versa. A company with large total assets is analogous to having the ability to carry out operational activities on a large scale so that the company can generate large profits as well. Companies that have a big advantage.

Large companies tend to have complex business activities, so stakeholders also have a tendency to monitor the company and this monitoring activity costs a lot too. According to Ousama, Fatima and Hafiz-Majdi (2012), large corporations have resources in abundant amount and company management is projected to deliver information related to the resources that companies use in carrying out company activities. According to Purnomosidhi (2006), companies with large sizes have a higher demand for openness than small companies, including agency cost. The company provides this information by disclosing intellectual capital as an effort to reduce this cost (Setyaningsih \& Prabawani, 2016).

Pratiwi (2016) also stated that companies with large sizes are more efficient and profitable performance even though economic conditions have decreased. So that it further reinforces that the larger the company size, the more disclosure of intellectual capital.

Faradina (2016), and Setiono and Rudiawarni (2017) delivered research results that firm size influence intellectual capital disclosure significantly. Constructed from this formulation, the proposed hypothesis in this research are as follows:

$\mathrm{H}_{1}$ : Firm size has a positive and significant effect on intellectual capital disclosure.

\section{The Influence of Leverage on Intellec- tual Capital Disclosure}

Banjarnahor (2019) argued that leverage is a comparison between the capitals injected by the company owner and the funds borrowed from creditors. If the funds obtained from creditors (debt) are higher, this means that the company has a high dependence on the debt. Companies with high debt levels can be interpreted as having poor performance, so companies need to provide information related to company performance in order to maintain good relations and reputation with creditors.

Asfahani (2017) stated that a firm with a high level of leverage will try to confirm that the firm's condition remains in good condition, even though it has a high level of dependence on debt. This is done by the company by providing high disclosure of intellectual capital information to creditors (Banjarnahor, 2019).

Research conducted by Bruggen, Vergauwen, and Dao (2009), and Asfahani (2017) exhibited that leverage has a positive and significant influence on 
intellectual capital disclosure. Based on this formulation, the hypothesis proposed in this study are as follows:

$\mathrm{H}_{2}$ : Leverage has a positive and significant effect on intellectual capital disclosure.

\section{The Influence of Audit Committee on Intellectual Capital Diclosure}

The audit committee is one of the components of corporate governance created by the board of commissioners. In addition, the audit committee is also responsible for carrying out its duties to the board of commissioners, including the firm financial audit. This will be used as information by the management of the company for decisions such as disclosing intellectual capital.

The audit committee as a component in corporate governance is also responsible for providing information. As stated by Aryati (2016), corporate governance disclosure includes providing information about company management, control, transparency and accountability to users. A good audit committee performance will reduce agency problems. Added again by Aryati (2016) that the smaller the agency problem, the better the company's performance. In this research, the company performance is the intellectual capital disclosure performance.

Muttakin, Khan, and Belal (2015), Li, Pike, and Haniffa (2008), and Li,
Mangena, and Pike (2012) which states that the audit committee has a positive effect on intellectual capital disclosure. Based on this formulation, the hypothesis proposed in this study are as follows:

$\mathrm{H}_{3}$ : The audit committee has a positive and significant effect on intellectual capital disclosure.

\section{The Influence of Business Complexity on Intellectual Capital Disclosure}

Banjarnahor (2019) defines business complexity as a company's business structure that is reflected in the sum of subsidiaries owned by a company. Companies with a large number of subsidiaries reflect complex company activities.

Companies with a large number of subsidiaries require high monitoring costs, so in an effort to reduce these costs, companies with numerous subsidiaries need to disclose intellectual capital. Thus, companies with a large number of subsidiaries tend to disclose intellectual capital.

This is in line with the results of research by Banjarnahor (2019) which states that business complexity has a positive and significant effect on intellectual capital disclosure. Based on this formulation, the hypothesis proposed in this study are as follows:

$\mathrm{H}_{4}$ : Business complexity has a positive and significant effect on intellectual capital disclosure

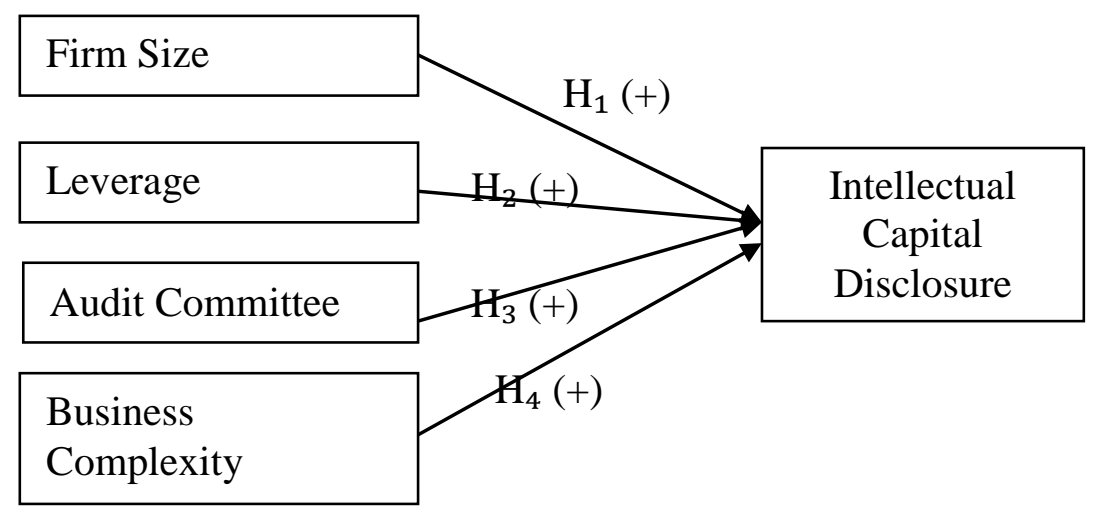

Figure 1. Conceptual Framework 


\section{RESEARCH METHODS}

The type of research approach in this research is quantitative approach which seeks to describe the findings constructed on the outcomes of hypothesis testing. The type of data deployed in this research is secondary data sourced on the IDX website at the link www.idx.co.id and the respective companies' websites.

\section{Dependent Variable}

The dependent variable deployed in this study is the Intellectual Capital Disclosure (ICD)1 in manufacturing firms in the basic industry and chemical subsectors. The measurement of the disclosure of a firm's intellectual capital uses an index adopted from Bukh et.al (2005). The disclosure index is classified into 6 groups consisting of 78 items. The following is a classification of the disclosure of intellectual capital.

Tabel 1 Classification of ICD

\begin{tabular}{lc}
\hline \multicolumn{1}{c}{ ICD Group } & Item \\
\hline Employees & 27 \\
Customer & 14 \\
IT & 5 \\
Process & 8 \\
R\&D & 9 \\
Strategic Report & 15 \\
\hline \multicolumn{2}{c}{ Source: Bukh et.al (2005) }
\end{tabular}

The company scoring, if the company discloses an item in accordance with the intellectual capital disclosure index, then it will be given a score of 1 , otherwise it will be given a score of 0 . Further, the score of every item is added up to obtain the total score of each firm. The measurement of the disclosure of the company's intellectual capital uses the intellectual capital disclosure index with the following formula:

ICD Indeks $=\frac{\Sigma \text { disclosures made by Co }}{78 \text { item }} \times 100 \% \ldots(1)$

\section{Independent Variable}

Independent variable deployed in this study are Firm Size, Leverage, a. Audit Committee, and Business Complexity. Firm Size, the company scoring, if the company discloses an item in accordance with the intellectual capital disclosure index, then it will be given a score of 1 , otherwise it will be given a score of 0 . Further, the score of every item is added up to acquire the total score of each company. The measurement of the disclosure of the firm's intellectual capital uses the intellectual capital disclosure index with the following formula:

Size Firm $=\operatorname{Ln}($ Total Assets $)$

Leverage is the ratio used to quantity a company's investment that is financed by debt. The scale used is the Total Debt to Equity Ratio, calculated by the proportion between total debt and equity.

DER $=\frac{\text { Total Liabilitas }}{\text { Total Equity }}$

The audit committee is selected and has responsibility to the commissioner's board to carry out its duties, including those related to company audits. The audit committee variable is measured by totalling the figure of audit committees in the study sample.

Banjarnahor (2019) defines business complexity as a company's business structure, namely the number of subsidiary entities. Thus business complexity is measured by counting the total of subsidiaries possessed by the research sample.

\section{Population, Number of Samples and Sampling Techniques}

This study's population were companies in manufacturing industry in the basic and chemical sub-sectors listed on the Indonesia Stock Exchange in 2019 with a overall of 70 firms. The sampling technique used was purposive sampling method. The use of this technique by providing criteria in determining the sample company. Determination of criteria 
was intended to select companies with data that were less valid for research. The criteria used are as follows: (a) Basic industrial and chemical sub-sector firms registered on the Indonesia Stock Exchange in the period of 2016-2019; (b) Basic industrial and chemical sub-sector companies that were not consistently registered on the Indonesia Stock Exchange in the period of 2016-2019; (c) Basic industry and chemical sub-sector companies that did not publish financial reports regularly from 2016-2019; (d) Basic industrial and chemical sub-sector firms that do not use the Indonesian currency in their financial statements; dan (e) Basic industrial and chemical subsector companies that do not issue final financial reports.

Of the 70 companies in the basic and chemical industry sectors listed on the IDX, there are 4 companies that are not registered consecutively from 2016-2019, 28 companies that do not publish financial reports consecutively from 2016-2019, 6 companies that do not use the rupiah currency in their financial reports, and 6 companies that do not publish their final financial reports. So that there are 26 companies used as research samples, with a research period of 4 years so that the total research sample is 104 companies.

The data gathering method in this research uses documentation study by taking sample company annual financial reports, analyzing data which includes recording and calculating data on dependent and independent variables. Using content analysis methods to measure and review variable data in annual reports.

\section{Descriptive Statistics}

Descriptive statistics are used to describe data related to research that has been collected by observing at the mean value, standard deviation, and maximum and minimum values (Ghozali, 2016).

\section{Classic Assumption Test}

The classic assumption tests that will be carried out in this study include Normality Test, Multicolinearity Test, Autocorrelation test, and Heteroscedasticity Test. The normality test purposes to check whether in the estimation model, confounding or residual variables have a normal distribution. Detect whether the residuals have a normal distribution or not with graphical analysis and statistical tests (Ghozali, 2016), namely by seeing at the p-plot graph and the Kolmogorov Smirnov (K-S) value.

The multicolinearity test states that the dependent variable must be free from multicolinearity symptoms. Symptoms of multicolinearity are symptoms of correlation between independent variables. Multicolinierity test detection is conducted by viewing at the Tolerance and VIF values.

The autocorrelation test is assumptions test in regression where the dependent variable is not connected with itself. The dependent variable value is not correlated to the value of the variable itself, either the value of the prior period or the value of the variable afterwards. Detection of autocorrelation symptoms, this study uses the Run test.

Heteroscedasticity is an supposition in regression where the variance of the residuals is not similar for individual observation to another. In regression, one of the important assumptions that must be encountered is that the variance of the residuals from one observation to another does not have a certain pattern (Santosa \& Ashari, 2005). The heteroscedasticity test in this study used the scatter plot test.

\section{Multiple Regression Analysis}

The multiple regression equation is a regression equation by two or more independent variables (Santosa \& Ashari, 2005). Hypothesis testing technique uses multiple regression analysis which is used to examine the effect of the audit committee, business complexity, company 
size and leverage. The multiple regression model is formulated as follows:

$$
\begin{aligned}
& I C D=\alpha+\beta_{1} S I Z E+\beta_{2} L e v+\beta_{3} A C+ \\
& \beta_{4} B C+e
\end{aligned}
$$

Explanation :

$$
\begin{array}{ll}
\text { ICD } & =\text { Intellectual Capital Disclosure } \\
\boldsymbol{\alpha} & =\text { Constant } \\
\boldsymbol{\beta} & =\text { Coefficient of regressing } \\
\text { SIZE } & =\text { Size Firm } \\
\mathbf{L e v} & =\text { Leverage } \\
\boldsymbol{A C} & =\text { Audit Committee } \\
\boldsymbol{B C} & =\text { Business Complexity } \\
\boldsymbol{e} & =\text { error }
\end{array}
$$

\section{Test of Hypothesis}

To determine the influence between the dependent variable and the independent variable, a hypothesis test is performed. Statistically, it can be estimated by the $\mathrm{t}$ test, F test, and the determination coefficient (Ghozali, 2016).

\section{RESULT AND DISCUSSION}

The statistical descriptive test purposes to give an overview or depiction of the data understood from the sum of samples, minimum value, maximum value, mean value, and each variable standard deviation. According to the statistical descriptive table 4.1 , it showed that the number of respondents (N) were 104 companies. ICD from 104 sample companies has a minimum value of 6.41 obtained by PT. Jakarta Kyoei Steel Works Tbk and a maximum value of 69.23 obtained by PT. Waskita Beton Precast Tbk. Meanwhile, the average company that disclosed intellectual capital was 32.152 or $32.12 \%$ with a lower standard deviation value of 1.211221 , this showed that the average (mean) ICD in the sample companies is sufficiently revealed in the annual report of the company.
The minimum and maximum values for the variable size are 25,714 and 31,037. This meant that the size of the firm as calculated by the normal log of total assets is the smallest $25.71 \%$ and the largest company size is $31.03 \%$. Meanwhile, the average size was $28.1 \%$. The minimum and maximum leverage values were $-5,272$ and 786,931 . This meant that the lowest proportion of company capital financed by debt was $\quad-5.27 \%$ and the highest proportion of company capital financed by debt was $786.93 \%$. Meanwhile, the average proportion of company capital that was financed by debt is $15.61 \%$.

The minimum and maximum values of the audit committee are 3 and 4. This means that the minimum and maximum number of audit committees was 3 and the maximum is 4. Meanwhile the average number of audit committees possessed by the sample companies was 3 . The minimum and maximum business complexity measured based on the number of subsidiaries owned by the sample companies is 0 and 24. This means that of the 104 sample companies the lowest value for business complexity was the company that does not have any subsidiaries and the lowest value for business complexity was the company that has 24 subsidiary companies. Meanwhile, on average, the sample companies have 3 subsidiaries.

\section{Normality test}

From Figure 2, the test outcomes confirm that the histogram graph demonstrates a normal data distribution pattern and the normal probability plot (PPlot) graph shows the points whose distribution follows the trend of the diagonal line. Therefore it can be resolved that the sample data in this research have encountered the normality assumption.

Based on the Kolmogorov-Smirnov (K-S) test outcomes in table 3, it indicates that the significance value of the dependent variable on disclosure of intellectual capital was 0.071 which indicated that the regression model satisfies the normality 
assumption, because it has a significance level of more than 0.05 . So that the Kolmogorov-Smirnov (K-S) test results were in line with the results of the normal probability plot (P-Plot) graph test, the conclusion was that the data was normally distributed.

\section{Multicollinearity Test}

Based on Table 4, it exhibited a tolerance value $\geq 0.10$ and a VIF value $\leq$ 10 for each variable. The resulting tolerance value for the variables of company size, leverage, audit committee size and business complexity was 0.786 ; $0.986 ; 0.929$ and 0.815 . Meanwhile, the resulting VIF value for the variables of company size, leverage, audit committee size and business complexity was 1.272; 1,$014 ; 1,076$; and 1,226. Based on the outcomes of the multicollinearity test, it can be stated that entire independent variables in the calculation model of regression did not have multicollinearity problems.

\section{Autocorrelation Test}

Durbin Watson (DW test) in the autocorrelation test on Table 5 resulted in a value of 0.814 , while based on the DW table $\mathrm{dU}=1.7582$ and $4-\mathrm{dU}=2.2781$. Because the value of $\mathrm{dU}>\mathrm{dw}<(4-\mathrm{dU})$, it was possible that the research sample has an autocorrelation problem. However, to get a more definite conclusion, the researchers conducted an autocorrelation test using another method, namely the Run Test.

Based on the results of the Run Test, it indicated that the test value was -1.07071 with the asymptotic value of the Run Test significance shown at 0.76 where the result was higher than the 0.05 significance level. So that it showed that the residual value was random or random, it can be stated that the data in this research did not have autocorrelation problems.

\section{Heteroscedasticity Test}

Based on Figure 3, it indicated that the points spread above and below the $\mathrm{Y}$ axis, so it can be stated that this research model did not occur heteroscedasticity.

Based on the table 6, the adjusted $\mathrm{R}^{2}$ value was 0.281 which meant that $28.1 \%$ of the variable level of intellectual capital disclosure (ICD) can be influenced by the size of firm, leverage, the number of audit committees and business complexity, while the remaining $71.9 \%$ is caused by factors or other variables from the external of regression model.

Regression equation was obtained as follows (based on table 7) :

$$
\begin{aligned}
& \text { ICD }=-139,575+6,089 \text { SIZE }+0,004 \\
& \mathrm{LEV}+0,166 \mathrm{AC}+0,006 \mathrm{BC}+\mathrm{e} \ldots \ldots . .(5)
\end{aligned}
$$

A constant of -139.575 meant that if the independent variable was valued constant (value 0), then the average disclosure was low, this mean that the influence of the independent variable on the dependent variable has a good model so that it deserved to be interpreted.

The regression coefficient for company size (X1) was 6,089. This coefficient was positive, which implies that the greater the size of the company, the greater the disclosure of intellectual capital. The leverage regression coefficient (X2) was 0.004. This coefficient is positive, the amount of leverage of a company will increase the disclosure of intellectual capital.

The audit committee regression coefficient (X3) is 0.166 . This coefficient was positive, which implies that the greater the number of audit committees the company has will incline the disclosure of intellectual capital. The business complexity regression coefficient (X4) was 0.006. This coefficient is positive, which suggest that the more complex the business structure in the company will increase the disclosure of intellectual capital. 


\section{Partial Effect Test (t Test)}

The partial effect test or $\mathrm{t}$ test purposes to analyze the influence of the independent variable on the dependent variable individually. The $\mathrm{t}$ statistic test can be conducted by observing at the probability value. The significance level of less than 0.05 indicates the result that Ho is rejected and $\mathrm{Ha}$ is accepted, which meant that there is an effect from the $\mathrm{X}$ to $\mathrm{Y}$ variables.

Table 7 displays that only the firm size variable (SIZE) has a significance value of less than 0.05 , so company size has a positive and significant effect on intellectual capital disclosure. However, for the variable leverage, audit committee and business complexity has a significance value of more than 0.05 , so it can be identified that these variables did not have a significant impact on the variable intellectual capital disclosure.

\section{F Test}

The simultaneous effect test or F test purposes to resolve whether all the independent variables that enter the model have a joint influence on the dependent variable (Ghozali, 2011). If the resulting significance value is less than 0.05 , it can be said that entire independent variables have a joint impact on the dependent variable.

The table 9 showed the amount of the calculated $\mathrm{F}$ value was 11.054 expressed as a positive indication, then the direction of the association is positive. The value statistically indicated a significant effect at $\alpha=0.05$, which is equivalent with 0.000 , which implies that the significance value $<0.05$. This designates that simultaneously the independent variables Firm Size, Leverage, Audit Committees and Business Complexity have a positive significant influence on the dependent variable on Intellectual Capital Disclosure (ICD). In addition, this significance value also shows the goodness of fit of a research model. If the value was less than 0.05 , it can be specified that the model deployed in the study is viable or has met.

\section{The Influence of Size Firm on Intellectual Capital Disclosure}

The firm size variable showed statistically significant results at $\alpha=0.05$, which is equal to 0.000 , so it can be stated that hal is accepted so that it can be decided that the firm size variable influences the level of intellectual capital disclosure (ICD). The beta value in this test was positive 0.553 , so the influence on intellectual capital disclosure was positive. The larger the size of a firm, the more information on intellectual capital disclosure will be provided to the public.

According to agency theory, agency costs for large companies are higher than for small firms. In addition, large companies also have greater conflicts between managers and stakeholders, which in turn will increase agency costs. According to Ousama et.al (2012), agency costs can be reduced by providing information in the form of voluntary disclosure, namely disclosure of intellectual capital.

The logic of thinking developed in this study is that companies with large sizes have all the resources that can support activities and this study deployed total assets as a representation of firm size. Thus, companies with large assets can generate large profits as well. A good internal management information system, related to various activities, can also be associated with a better ability to disclose information, including disclosure of intellectual capital. This is important because this is one of the company's efforts to encounter the requirements of users of financial statements and to maintain working relationships. Ousama et.al (2012) stated that large firms have large resources and company management is projected to provide information related to the resources that companies use in carrying out company activities. This research data shows that $50 \%$ of the research sample has 
total assets that exceed the average, so this can support the research results.

The results of this investigation were also supported by the results of Faradina (2016), Isnalita (2018), Leonard (2015), Setiono \& Rudiawarni (2017) which state that firm size has a positive effect on the level of intellectual capital disclosure.

\section{The Influence of Leverage on Intellectual Capital Disclosure}

The leverage variable was statistically insignificant at $\alpha=0.05$, which is 0.691. Judging from the significance value of more than $0.05(0.691>0.05)$, it can be stated that $\mathrm{Ha} 2$ is rejected, therefor it can be stated that the leverage variable has no influence on the proportion of intellectual capital disclosure. Each company does have its own strategy in satisfying the rights of creditors, especially in terms of disclosing information on the firm's intellectual capital, so that the size of the firm's leverage is not always proportional to the disclosed intellectual capital.

This was proven by that of the 104 research samples, there are 42 research samples that have a low level of leverage giving high intellectual capital disclosure, while 57 research samples that have a low level of leverage provide a low level disclosure of intellectual capital. The research sample is said to have a high or low level of leverage by comparing it with the average value of leverage in descriptive statistics. If the leverage value of the research sample is bigger than the average value, it can be said that the research sample has a great degree of leverage and vice versa. Thus, the level of leverage in the research sample does not influence the level of intellectual disclosure. In theory, companies with large debts will try to provide broad information. However, disclosures that are voluntary have not been fully disclosed.
According to Isnalita (2018), the insignificance of leverage on intellectual capital disclosure can be caused by the company's strategy. High agency costs can arise due to conflicts between investors and managers and high levels of leverage. Disclosure of the company's intellectual capital is done to reduce agency costs. However, companies also need to consider the advantages and disadvantages of disclosing intellectual capital.

The research result conducted by Ashari and Putra (2016), Faradina (2016), and Nugroho (2012) supported the findings of this research. In his research, it was explained that leverage has no influence on the level of intellectual capital disclosure.

\section{The Influence of Audit Committee on Intellectual Capital Diclosure}

The third independent variable, namely the audit committee, showed statistically insignificant results at $\alpha=$ 0.05 , which is 0.981. Judging from the significance value of more than 0.05 $(0.981>0.05)$, this indicated that the audit committee variable did not affect the level of intellectual capital disclosure.

This was supported by the fact that of the 104 research samples it showed that there are 45 research samples that have a low level of audit committee giving high intellectual capital disclosure, while 56 research samples that have a low audit committee level give a low intellectual capital disclosure. The research sample is said to have a high or low level of the audit committee by comparing it with the average value of the audit committee in descriptive statistics. If the research sample audit committee value is higher than the average value, it can be said that the research sample has a high audit committee level and vice versa. Thus, the level of audit committee research sample did not influence the level of intellectual disclosure.

OJK Regulation number 55 / Pojk.04 / 2015 concerning the establish- 
ment and guidelines for the implementtation of audit committee work states that the company has at least 3 audit committees from independent commissioners and outside parties of the issuer. With these rules, the company seeks to meet these criteria, so that the function of the audit committee in the company becomes ineffective. Another reason that may occur is because the independent commissioner is part of the audit committee and has not fully carried out their responsibilities independently (Taliyang \& Jusop, 2011). In addition, Fauziah and Marissan (2014) stated that in one company the audit committee can carry out multiple positions (duality) which makes the performance of the audit committee not optimal. Supported by Bronson et. al. (2009) explained that the role of the audit committee is fully achievable if the audit committee is truly independent.

The outcomes of this research were supported by the results of research by Isnalita (2018), Li et.al (2012), Taliyang and Jusop (2011), and Zulkarnaen (2013) which state that the size of the audit committee has no influence on the level of intellectual capital disclosure. .

\section{The Influence of Business Complexity on Intellectual Capital Disclosure}

The business complexity variable showed statistically insignificant results at $\alpha=0.05$, which is 0.983 . Judging from the significance value of more than 0.05 (0.983>0.05), this indicated that business complexity has no influence on the intellectual capital disclosure level, so that Ha4 was not accepted. This is consistent with an opinion that external parties or investors who tend to rely more on financial than non-financial information make it in the absence of interest for management to disclose more intellectual capital.

This was evidenced by the fact that of the 104 research samples it shows that there are 32 research samples that have a low level of business complexity giving high intellectual capital disclosure, while 44 research samples that have a low level of business complexity provide low intellectual capital disclosure. The research sample was said to have a high or low level of business complexity by comparing it with the average value of business complexity in descriptive statistics. If the business complexity value of the research sample is larger than the average value, it can be said that the research sample has a high level of business complexity and vice versa. Thus, the level of business complexity of the research sample does not affect the level of intellectual disclosure. Companies with complex business structures do need a management information system that is effective in monitoring, but in fact this does not always lead to higher IC disclosure.

Chemical and basic industrial companies are companies whose main segments are closely related to $R \& D$ and technology and knowledge activities. Sharma and Dharni (2017), in their research, revealed that companies that are related to these activities have reached the peak of the trend of increasing intellectual capital disclosure, leaving no more areas for an increase in the trend of intellectual capital disclosure. Thus, the relationship between business complexity or business segments has no effect.

The findings of this study were consistent with the research results of Jindal and Kumar (2012), and Setiono and Rudiawarni (2017), which stated that there is no relationship or influence of business complexity on the level of intellectual capital disclosure. 
Table 2. Result of Descriptive Statistics

Descriptive Statistics

\begin{tabular}{llrrrr}
\hline & N & Minimum & Maximum & Mean & Std. Deviation \\
\hline SIZE & 104 & 25.714 & 31.037 & 28.09979 & 1.211221 \\
LEV & 104 & -5.272 & 786.931 & 15.60977 & 100.606744 \\
AC & 104 & 3 & 4 & 3.03 & .168 \\
BC & 104 & 0 & 24 & 2.52 & 4.215 \\
ICD & 104 & 6.41 & 69.23 & 32.1252 & 13.33402 \\
Valid N (listwise) & 104 & & & & \\
\hline
\end{tabular}

Source: Secondary Data Processed (2020)

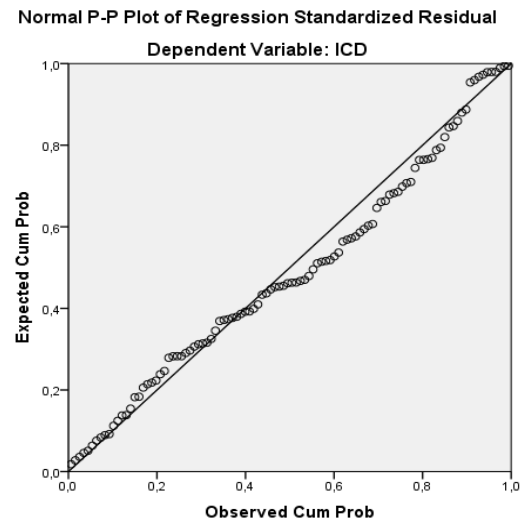

Figure 2. P-Plot of Regression Standardized Residual (Normality Test) Source: Secondary Data Processed (2020)

Table 3. Result of One-Sample Kolmogorov-Smirnov Test (Normality Test) One-Sample Kolmogorov-Smirnov Test

\begin{tabular}{llr}
\hline & & $\begin{array}{c}\text { Unstandardized } \\
\text { Residual }\end{array}$ \\
\hline $\mathrm{N}$ & Mean & 104 \\
Normal Parameters & & .0000000 \\
& Std. Deviation & 11.08619416 \\
Most Extreme Differences & Absolute & .084 \\
& Positive & .084 \\
& Negative & -.054 \\
Test Statistic & & .084 \\
Asymp. Sig. (2-tailed) & & $.071^{\mathrm{c}}$ \\
\hline
\end{tabular}

a. Test distribution is Normal.

b. Calculated from data.

c. Lilliefors Significance Correction.

Source: Secondary Data Processed (2020) 
Tabel 4. Result of Multicolinierity Test

\section{Coefficients $^{\mathrm{a}}$}

\begin{tabular}{|c|c|c|c|c|c|c|}
\hline \multirow{2}{*}{\multicolumn{2}{|c|}{ Model }} & \multicolumn{2}{|c|}{$\begin{array}{l}\text { Unstandardized } \\
\text { Coefficients }\end{array}$} & \multirow{2}{*}{$\begin{array}{c}\text { Standardized } \\
\text { Coefficients } \\
\text { Beta }\end{array}$} & \multicolumn{2}{|c|}{ Collinearity Statistics } \\
\hline & & $\mathrm{B}$ & Std. Error & & Tolerance & VIF \\
\hline 1 & (Constant) & -139.575 & 39.685 & & & \\
\hline & SIZE & 6.089 & 1.037 & .553 & .786 & 1.272 \\
\hline & LEV & .004 & .011 & .034 & .986 & 1.014 \\
\hline & $\mathrm{AC}$ & .166 & 6.873 & .002 & .929 & 1.076 \\
\hline & $\mathrm{BC}$ & .006 & .293 & .002 & .815 & 1.226 \\
\hline
\end{tabular}

a. Dependent Variable: ICD

Source: Secondary Data Processed (2020)

Table 5. Result of Runs Test (Autocorelation Test)

\begin{tabular}{lr}
\multicolumn{2}{c}{ Runs Test } \\
\hline & $\begin{array}{c}\text { Unstandardize } \\
\text { d Residual }\end{array}$ \\
\hline Test Value $^{\mathrm{a}}$ & -1.07071 \\
Cases $<$ Test Value & 52 \\
Cases $>=$ Test Value & 52 \\
Total Cases & 104 \\
Number of Runs & 44 \\
$Z$ & -1.774 \\
Asymp. Sig. (2- & .076 \\
tailed) & \\
\hline a. Median &
\end{tabular}

Source: Secondary Data Processed (2020)

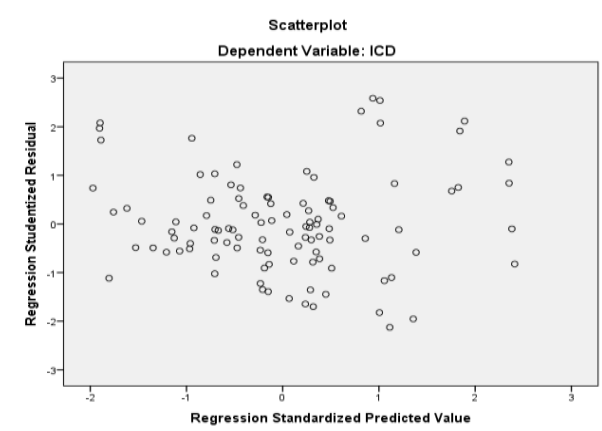

Figure 3. Scatter Plot (Heteroskedasticity Test)

Source: Secondary Data Processed (2020) 
Table 6. Determination Coefficient Result

\begin{tabular}{llrrrr}
\multicolumn{8}{c}{ Model Summary $^{\mathbf{b}}$} \\
\hline Model & $\mathrm{R}$ & R Square & $\begin{array}{c}\text { Adjusted R } \\
\text { Square }\end{array}$ & $\begin{array}{c}\text { Std. Error of the } \\
\text { Estimate }\end{array}$ & $\begin{array}{c}\text { Durbin- } \\
\text { Watson }\end{array}$ \\
\hline 1 & $.556^{\text {a }}$ & .309 & .281 & 11.30794 & .814 \\
\hline
\end{tabular}

a. Predictors: (Constant), BC, AC, LEV, SIZE

b. Dependent Variable: ICD

Source: Secondary Data Processed (2020)

Table 7. Result of Regression Test and t Test

Coefficients $^{\mathrm{a}}$

\begin{tabular}{lrrrrrr}
\hline & \multicolumn{2}{c}{$\begin{array}{c}\text { Unstandardized } \\
\text { Coefficients }\end{array}$} \\
& \multicolumn{1}{c}{$\begin{array}{l}\text { Standardized } \\
\text { Coefficients }\end{array}$} & & \\
Model & \multicolumn{1}{c}{ S } & \multicolumn{1}{c}{ Error } & Beta & \multicolumn{1}{c}{ T } & \multicolumn{1}{c}{ Sig. } \\
\hline 1 & (Constant) & -139.575 & 39.685 & & -3.517 & .001 \\
& SIZE & 6.089 & 1.037 & .553 & 5.870 & .000 \\
LEV & .004 & .011 & .034 & .399 & .691 \\
AC & .166 & 6.873 & .002 & .024 & .981 \\
BC & .006 & .293 & .002 & .021 & .983 \\
\hline
\end{tabular}

a. Dependent Variable: ICD

Source: Secondary Data Processed (2020)

Tabel 8. Result of F test

\begin{tabular}{|c|c|c|c|c|c|}
\hline \multicolumn{6}{|c|}{ ANOVA $^{\mathrm{a}}$} \\
\hline Model & $\begin{array}{l}\text { Sum of } \\
\text { Squares }\end{array}$ & Df & $\begin{array}{l}\text { Mean } \\
\text { Square }\end{array}$ & $\mathrm{F}$ & Sig. \\
\hline Regression & 5653.905 & 4 & 1413.476 & 11.054 & $.000^{\mathrm{b}}$ \\
\hline Residual & 12659.081 & 99 & 127.870 & & \\
\hline Total & 18312.986 & 103 & & & \\
\hline
\end{tabular}

a. Dependent Variable: ICD

b. Predictors: (Constant), BC, AC, LEV, SIZE

Source: Secondary Data Processed (2020)

\section{CONCLUSION AND RECOMMEN- DATION}

Based on the results and discussion above, conclusions in this study include: 1) the firm size variable has an influence on intellectual capital disclosure. Large companies can generate large profits and are supported by a good internal management information system, so that they have the ability to properly disclose intellectual capital. 2) The leverage variable does not have a significant influence on intellectual capital disclosure. The level of leverage does not affect the level of intellectual disclosure. In theory, companies with large debts will try to 
provide broad information. However, disclosures that are voluntary have not been fully disclosed. 3) The audit committee variable does not have a significant influence on intellectual capital disclosure. The high and low number of audit committees in the company has no effect on intellectual capital disclosure. The company strives to encounter the standard number of audit committees set by the government, however, it has not been able to fully contribute to the disclosure of intellectual capital. 4) The business complexity variable does not have a significant effect on intellectual capital disclosure. The level of business complexity of the research sample does not influence the level of intellectual disclosure. Companies with complex business structures need management information systems that are effective in monitoring, but in fact this does not always lead to higher disclosure of intellectual capital.

As for the suggestions for the next research, it should be able to augment other variables that can influence intellectual capital disclosure like corporate governance mechanisms, market share and so on. This is because the coefficient of determination generated in this study is only $28.1 \%$, so that other variables are needed that need to be added in the next research. In addition to adding variables, subsequent research can conduct research on other objects such as in the area of education. The issue of disclosing intellectual capital still requires further study, but on the company side it also requires attention. Disclosure of intellectual capital is very necessary to meet needs and maintain sustainable relationships with users.

\section{REFERENCES}

Afrizal, S., Hakiem, N., \& Sensuse, D. I. (2015). Analisis Kesiapan Implementasi E-government Pada Direktorat Jendral Penyelenggaraan Haji Dan Umrah Kementerian Agama Republik Indonesia. Jurnal Sistem Informasi, 11(2), 88-92.

Aisyah, C. N., \& Sudarno, S. (2014). Pengaruh Struktur Kepemilikan dan R\&D Terhadap Luas Pengungkapan Modal Intelektual. Diponegoro Journal of Accounting, 233-241.

Aryati, T. (2016). Pengaruh Kinerja Perusahaan Terhadap Corporate Governance Reporting Dengan Variabel Moderating CEO Tenure. Media Ekonomi dan Manajemen, 29(1), 30-43.

Asfahani, E. S. (2017). Pengaruh ukuran perusahaan, profitabilitas, leverage, umur perusahaan dan kepemilikan pemerintah terhadap pengungkapan intellectual capital. E-Journal Akuntansi EQUITY, 3(3), 40-61 .

Ashari, P. M. S., \& Putra, I. N. W. A. (2016). Pengaruh Umur Perusahaan, Ukuran Perusahaan, Profitabilitas, Leverage Dan Komisaris Independen Terhadap Pengungkapan Modal Intelektual. E-Jurnal Akuntansi Universitas Udayana, 3(14), 16991726.

https://ojs.unud.ac.id/index.php/Aku ntansi/article/view/14711

Balasundaram, N. (2018). Audit Committee Characteristics and Their Impact on Intellectual Capital Disclosure: a Study of Listed Manufacturing Companies in Sri Lanka. Asia-Pacific Management Accounting Journal, 14(1), 135-149. http://ir.uitm.edu.my/id/eprint/29368/ 1/29368.pdf

Banjarnahor, E. (2019, April). Intellectual Capital Disclosure Perusahaan Perbankan di Indonesia. In Prosiding Seminar Nasional Pakar, 2-22. 
Boedker, C., Guthrie, J., \& Cuganesan, S. (2005). An Integrated Framework for visualing intellectual capital. Journal of Intellectual Capital, Vol. 6 No. 4, 510-527.

Bruggen, A, Vergauwen, P, \& Dao, M. (2009). Determinants of Intellectual Capital Disclosure: Evidence from Australia. Journal of Management Decision, 47(2), 233-24

Bukh, P.N. (2003). The relevance of intellectual capital disclosure: a paradox?. Accounting, Auditing and Accountability Journal, 16(1), 49-56.

Damayanti, T., \& Budiyanawati, A. (2014). The Effect of Firm Characteristic on Intellectual Capital Disclosure in Islamic Banking: Evidence From Asia. Tazkia Islamic Finance and Business Review, 4(2), 721-740.

https://media.neliti.com/media/public ations/271326-the-effect-of-firmcharacteristic-on-int-6729a2a5.pdf

Fajarrisqim, S., Amin, M., \& Afifudin, A. (2018). Pengaruh Firm Size, Tipe Industri, Leverage Pada Pengungkapan Modal Intelektual (Studi Empiris Perusahaan Manufaktur Yang Listing Di BEI Tahun 2014-2016). Jurnal Ilmiah Riset Akuntansi, 7(05), 112-125.

Faradina, S. (2016). Faktor-Faktor Yang Mempengaruhi Pengungkapan Intellectual Capital Pada Perusahaan Property Dan Real Estate. Esensi Jurnal Bisnis Dan Manajemen, 5(2), 305-326.

https://doi.org/10.15408/ess.v5i2.235 $\underline{0}$

Fauziah, F. E., \& Marissan, I. (2014). Pengaruh corporate social responsibility (CSR) terhadap kualitas laba dengan corporate governance sebagai variabel moderating. Jurnal Akuntansi dan Auditing, 11(1), 39-61.
Ghozali, I. dan Anis Chariri, A. (2007). Teori Akuntansi. Semarang: Badan Penerbit Universitas Diponegoro.

Ghozali, P. D. (2016). Aplikasi Analisis Multivariate Dengan Program Ibm SPSS 21. Semarang: Badan Penerbit Universitas Diponegoro.

Ghozali, Imam. (2011). Aplikasi Analisis Multivariate dengan Program IBM SPSS 19. Semarang : Badan Penerbit Universitas Diponegoro.

Haji, A. A. (2015). The role of audit committee attributes in intellectual capital disclosures. Managerial Auditing Journal, 30(8/9), 756-784.

Haniffa, R. M., \& Cooke, T. E. (2002). Culture, Corporate Governance and Disclosure in Malaysian Corporations. A Journal of Accounting, Finance and Bussiness Studies, 38(3), 317-349. https://doi.org/10.1111/14676281.00112

Hatane, S. E., Kuanda, E. S., Cornelius, E., \& Tarigan, J. (2020). Corporate Governance, Market Share, and Intellectual Capital Disclosure: Evidence from the Indonesian Agriculture and Mining Sectors. Jurnal Ilmiah Akuntansi Dan Bisnis, 15(1), 75-84. https://doi.org/10.24843/jiab.2020.v1 5.101.p07

Ho, S. S., \& Shun Wong, K. (2001). A study of the relationship between corporate governance structures and the extent of voluntary disclosure. Journal of International Accounting, Auditing and Taxation, 10(2), 139156.

Hossain, M., \& Hammami, H. (2009). Voluntary disclosure in the annual reports of an emerging country: The case of Qatar.Advances in Accounting, 25(2), 255-265. 
Isnalita, F. R. (2018). The Effect of Company Characteristics and Corporate Governance on the Practices of Intellectual Capital Disclosure. International Research Journal of Business Studies, 11(3), 217-230.

https://doi.org/10.21632/irjbs.11.3.21 7-230

Jindal, S., \& Kumar, M. (2012). The determinants of $\mathrm{HC}$ disclosures of Indian firms. Journal of Intellectual Capital, 13(2), 221-247. https://doi.org/10.1108/14691931211 225049.

Leonard, D. (2015). Pengaruh Karakteristik Dan Fundamental Perusahaan Terhadap Pengungkapan Modal Intelektual. Jurnal Bisnis Dan Akuntansi, $\quad$ 17(2), $\quad$ 168-177. https://doi.org/10.34208/jba.v17i2.28

Li, J., Mangena, M., \& Pike, R. (2012). The effect of audit committee characteristics on intellectual capital disclosure. British Accounting Review, 44(2), 98-110. https://doi.org/10.1016/j.bar.2012.03. 003.

Li, J., Pike, R., \& Haniffa, R. (2008). Intellectual capital disclosure and corporate governance structure in UK firms. Accounting and business research, 38(2), 137-159.

Marr, B., Mouritsen, J., and Bukh, P.N. (2003). Perceived Wisdom. Financial Management, July/August, p. 32

Muttakin, M. B., Khan, A., \& Belal, A. R. (2015). Intellectual capital disclosures and corporate governance: An empirical examination. Advances accounting, 31(2), 219-227.

Nafisah, L., \& Meiranto, W. (2017). Pengaruh karakteristik perusahaan terhadap pengungkapan modal intelektual dalam prospektus IPO. Diponegoro Journal of Accounting, 6(3), 635-645.
Nugroho, A. (2012). Faktor-Faktor Yang Mempengaruhi Intellectual Capital Disclosure (Icd). Accounting Analysis Journal, 1(2), 1-11. https://doi.org/10.15294/aaj.v1i2.702

Ousama, A.A., Fatima, A.-H. \& HafizMajdi, A. R. (2012). Determinants of intellectual capital reporting: Evidence from annual reports of Malaysian listed companies. Journal of Accounting in Emerging Economies, 2(2), http://www.emeraldinsight.com/doi/a bs/10.1108/20421161211229808

Pratiwi, M. W. (2016). Pengaruh Ukuran Perusahaan Terhadap Reaksi Pasar Yang Dimoderasi Investment Opportunity Set. Media Ekonomi dan Manajemen, 25(1), 58-71.

Purnomosidhi, B. (2006). Analisis empiris terhadap determinan praktik pengungkapan modal intelektual pada perusahaan publik di BEJ. Jurnal riset akuntansi Indonesia, 9(1), 1-20.

Rashid, A. A., Ibrahim, M. K., Othman, R., \& See, K. F. (2012). IC disclosures in IPO prospectuses: Evidence from Malaysia. Journal of Intellectual Capital, 13(1), 57-80. https://doi.org/10.1108/14691931211 196213

Scott, B. N., Carcello, J. V., Hollingsworth, C. W., \& Neal, T. L. (2009). Are fully independent audit committees really necessary?. Journal of Accounting and Public Policy. 28(4), 265-280.

Setiono, I. N., \& Rudiawarni, F. A. (2017). Analisis Pengaruh Karakteristik Perusahaan Terhadap Human Capital Disclosure Pada Perusahaan High IC Intensive Industries Yang Terdaftar Di BEI Periode 2009-2011. Jurnal Ilmiah Mahasiswa Universitas Surabaya, 1(1), 1-16. http://doi.org/10.5281/zenodo.15610 97 
Setyaningsih, R. N., \& Prabawani, B. (2016). Faktor-faktor Yang Mempengaruhi Pengungkapan Modal Intelektual Studi Empiris Pada Perusahaan Yang Listing Di Jakarta Islamic Index 20122014. Jurnal Ilmu Administrasi Bisnis, 5(3), 66-79.

Sharma, S., \& Dharni, K. (2017). Intellectual capital disclosures in an emerging economy: status and trends. Journal of Intellectual Capital.

Subaida, I., Nurkholis, N., \& Mardiati, E. (2018). Effect of Intellectual Capital and Intellectual Capital Disclosure on Firm Value. Jurnal Aplikasi Manajemen, 16(1), 125-135.

Suhardjanto, D \& Wardhani, M. (2010). Praktik Intellectual Capital Disclosure Perusahaan Yang Terdaftar di Bursa Efek Indonesia. JAAI, 14(1), 71-85

Sujoko, \& Soebiantoro, U. (2007). Pengaruh Struktur Kepemilikan Saham, Leverage, Faktor Intern, Dan Faktor Ekstern Terhadap Nilai Perusahaan. Jurnal Ekonomi Manajemen, 9(1), 41-48.

Taliyang, S. M., \& Jusop, M. (2011). Intellectual Capital Disclosure and Corporate Governance Structure: Evidence in Malaysia. International Journal of Business and Management, 6(12), 109-117. https://doi.org/10.5539/ijbm.v6n12p1 $\underline{09}$

www.ojk.go.id, 2015, POJK Nomor 55/POJK.04/2015,Pembentukan dan Pedoman Pelaksanaan Kerja Komite Audit

Zulkarnaen, E. I. (2013). Pengaruh Good Corporate Governance Terhadap Luas Pengungkapan Intellectual Capital. Jurnal Dinamika Akuntansi, 5(1), 79-85. https://doi.org/10.15294/jda.v5i1.256 5 